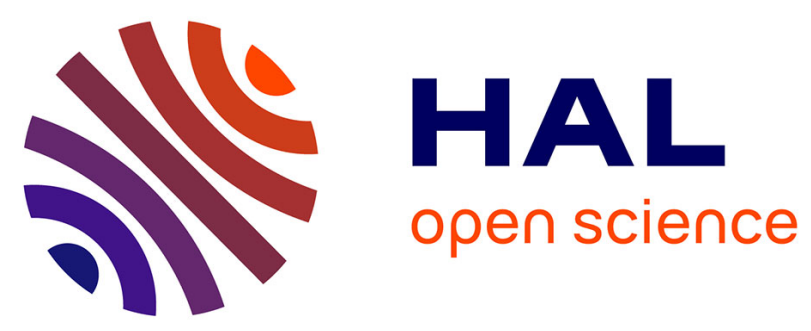

\title{
Relations between peripartum concentrations of prolactin and progesterone in sows and piglet growth in early lactation
}

Hélène Quesnel, Peter Ramaekers, Hubèrt van Hees, Chantal Farmer

\section{- To cite this version:}

Hélène Quesnel, Peter Ramaekers, Hubèrt van Hees, Chantal Farmer. Relations between peripartum concentrations of prolactin and progesterone in sows and piglet growth in early lactation. Canadian Journal of Animal Science, 2013, 93 (1), pp.109-112. 10.4141/CJAS2012-106 . hal-01210388

\author{
HAL Id: hal-01210388 \\ https://hal.science/hal-01210388
}

Submitted on 29 May 2020

HAL is a multi-disciplinary open access archive for the deposit and dissemination of scientific research documents, whether they are published or not. The documents may come from teaching and research institutions in France or abroad, or from public or private research centers.
L'archive ouverte pluridisciplinaire $\mathbf{H A L}$, est destinée au dépôt et à la diffusion de documents scientifiques de niveau recherche, publiés ou non, émanant des établissements d'enseignement et de recherche français ou étrangers, des laboratoires publics ou privés. 


\title{
SHORT COMmunication: Relations between peripartum concentrations of prolactin and progesterone in sows and piglet growth in early lactation
}

\author{
Hélène Quesnel ${ }^{1,2}$, Peter Ramaekers ${ }^{3}$, Hubèrt van Hees $^{3}$, and Chantal Farmer ${ }^{4,5}$ \\ ${ }^{1}$ INRA, UMR1348 Physiologie, Environnement et Génétique pour l'Animal et les Systèmes d'Élevage, F-35590 \\ Saint-Gilles, France; ${ }^{2}$ Agrocampus Ouest, UMR1348 PEGASE, F-35000 Rennes, France; ${ }^{3}$ Nutreco R\&D, \\ P.O. Box 2205830 AE Boxmeer, the Netherlands; and ${ }^{4}$ Agriculture and Agri-Food Canada, Dairy and Swine \\ R\&D Centre, 2000 College, Sherbrooke, Québec, Canada J1M OC8. \\ Received 7 September 2012, accepted 26 October 2012.
}

\begin{abstract}
Quesnel, H., Ramaekers, P., van Hees, H. and Farmer, C. 2013. Short Communication: Relations between peripartum concentrations of prolactin and progesterone in sows and piglet growth in early lactation. Can. J. Anim. Sci. 93: $109-112$. Postpartum hypogalactia has been suggested to be related to an impaired secretion of prolactin or to elevated concentrations of progesterone around farrowing. In the current study, peripartum circulating concentrations of prolactin and progesterone were determined in 50 multiparous sows (parities 1 to 5) and related to the $\mathrm{Na} \mathrm{K}^{-1}$ ratio and lactose in colostrum and to piglet growth in early lactation. An effect of parity $(P<0.001)$ was observed for prolactin, with sows from parity 1 having lower concentrations than sows from parities 2, 3, 4 and 5, and sows from parities 4 and 5 having the greatest concentrations. Piglet growth from day 1 to day 5 was negatively correlated with progesterone concentrations in sows on day $1(r=-0.36, P=0.01)$. The present study supports the hypothesis of a negative impact of high concentrations of progesterone after farrowing on early growth of piglets and also shows a clear effect of sow parity on the peripartum concentrations of prolactin suggesting that younger sows are more vulnerable to reduced milk yield due to lower prolactin concentrations.
\end{abstract}

Key words: Colostrum, piglet growth, peripartum, progesterone, prolactin

\begin{abstract}
Quesnel, H., Ramaekers, P., van Hees, H. et Farmer, C. 2013. Brève Communication: Relations entre les concentrations de prolactine et de progestérone chez des truies en péripartum et la performance des porcelets en début de lactation. Can. J. Anim. Sci. 93: 109-112. Des concentrations trop basses de prolactine ou trop élevées de progestérone en péripartum sont des causes potentielles d'hypogalactie chez la truie. Dans le présent projet, les concentrations sanguines de prolactine et de progestérone autour de la mise bas ont été mesurées chez 50 truies multipares (parités 1 à 5) et les relations avec le lactose et le ratio $\mathrm{Na} \mathrm{K}^{-1}$ dans le colostrum, ainsi que la croissance des porcelets en début de lactation ont été étudiées. Il y avait un effet de parité sur les concentrations de prolactine $(P<0.001)$, les truies de parité 1 ayant des valeurs plus basses que les truies des parités $2,3,4$ et 5, et les truies de parité 4 et 5 ayant les valeurs les plus élevées. Il y avait une corrélation négative entre la croissance des porcelets des jours 1 à 5 et les concentrations de progestérone chez les truies au jour $1(r=-0.36$, $P=0.01)$. La présente étude corrobore l'hypothèse d'un impact négatif de concentrations élevées de progestérone après la mise bas sur la croissance des porcelets en début de lactation. Une démonstration claire d'un effet de parité sur les concentrations de prolactine en péripartum suggère que les truies primipares sont plus vulnérables à une diminution de la production laitière causée par des taux de prolactine trop bas.
\end{abstract}

Mots clés: Colostrum, croissance des porcelets, péripartum, progestérone, prolactine

An adequate colostrum and milk intake during the first days after birth is critical for piglet growth and survival before weaning (Le Dividich et al. 2005; Devillers et al. 2011). Prolactin and progesterone play a key role in the initiation of milk production (Taverne et al. 1982; Farmer et al. 1998). Moreover, an alteration in prolactin and progesterone profiles around farrowing could be involved in poor colostrum production by sows and increased piglet mortality (Foisnet et al. 2010). There are

${ }^{5}$ Corresponding author (email: chantal.farmer@) agr.gc.ca). indications that parity could affect concentrations of prolactin $24 \mathrm{~h}$ post-partum (Farmer et al. 1995), yet, to the best of our knowledge, the effect of parity per se on peripartal prolactin concentrations has never been studied. The objectives of the current trial were to study the potential relations between peripartal concentrations of prolactin and progesterone in sows and indicators of colostrum yield (i.e., piglet growth in the first $24 \mathrm{~h}$ postpartum) and mammary epithelium integrity, as well as piglet growth up to day 5 after birth. The effect of parity on peripartal concentrations of prolactin and progesterone in sows was also determined. 
The experiment was conducted at the research farm "Halfweg" of Nutreco Swine Research Centre Boxmeerseweg 30, 5845 ET, Sint Anthonis, the Netherlands and was approved by the animal ethical committee of Utrecht University. Present data were collected as an offshoot of a trial looking at two feeding strategies for sows in late gestation. This treatment had no significant effect on any of the variables studied currently so that data on all animals could be used. The feeding strategies during the last week of pregnancy were that sows received either $3 \mathrm{~kg}$ of feed daily or $6 \mathrm{~kg}$ every other day. The diet was formulated for lactating sows $\left(9.11 \mathrm{MJ} \mathrm{NE} \mathrm{kg}{ }^{-1}, 17.8 \%\right.$ crude protein, $0.8 \%$ lysine, and $4.4 \%$ crude fibre). As of the day of farrowing (day 0 ), feed supply was progressively increased $(3.0,4.0,4.5,5.0$, and $5.5 \mathrm{~kg}$ on days $0,1,2,3$, and 4 , respectively). A total of 61 Hypor (synthetic Dutch Landrace sow $\times$ synthetic Dutch Large White boar) sows from parity 1 to 5 were used over four batches. Because litter size is known to influence piglet weight gain during lactation, variation in litter size was reduced by focussing the study on sows that nursed 10 to 16 piglets during the first $24 \mathrm{~h}$ after farrowing (before crossfostering), which left 50 sows (parity $1, n=8$; parity 2 , $n=15$; parity $3, n=8$; parity $4, n=7$; parity $5, n=12$ ). Sows were weighed upon entering the farrowing room (day 108 of gestation) and backfat thickness was also measured ultrasonically (Renco Lean meater ${ }^{\circledR}$, Renco Corporation, Minneapolis, MN). Farrowing was not induced and during farrowing, interventions were kept to a minimum. Piglets were weighed individually at the end of farrowing, $24 \mathrm{~h}$ later and on day 5 of lactation. Until the second weighing, the original litter was kept with the sow and piglets received no treatments (no castration, no iron treatment). After this second weighing, piglets received an iron injection with $1 \mathrm{mg}$ Farmosan Ursoferran $\left(200 \mathrm{mg} \mathrm{Fe} \mathrm{mL}^{-1}\right.$, Trouw Nutrition, Putten, the Netherlands) and litters were standardized to 12-14 piglets by cross-fostering within treatment groups. Piglets were not castrated during the trial.

A catheter was inserted non-surgically in the jugular vein of sows 4 or $5 \mathrm{~d}$ before farrowing, according to a previously described method (Matte 1999). Blood samples $(20 \mathrm{~mL})$ were collected on the day before the expected farrowing date (day -1), at the onset of farrowing (day 0), and $24 \mathrm{~h}$ after the onset of farrowing (day 1). The time elapsed between the first blood sampling (day -1) and farrowing was calculated a posteriori. It averaged $22.7 \pm 1.0 \mathrm{~h}$ and ranged from 3 to $37 \mathrm{~h}$. Blood was collected in tubes containing heparin for plasma preparation $(15 \mathrm{~mL})$ and containing no anticoagulant for serum preparation $(5 \mathrm{~mL})$. Heparinized samples were immediately centrifuged for $10 \mathrm{~min}$ at $1036 \times g$. Samples without anticoagulant were kept at ambient temperature for $4 \mathrm{~h}$, stored overnight $20 \mathrm{~h}$ at $4^{\circ} \mathrm{C}$ then centrifuged for $12 \mathrm{~min}$ at $1512 \times \mathrm{g}$. Colostrum samples $(17 \mathrm{~mL})$ were collected at the onset of farrowing from several mammary glands across the udder of each sow. Colostrum was filtered on gauze tissue. Plasma, serum, and colostrum samples were stored at $-20^{\circ} \mathrm{C}$ until analyses.

Blood samples were assayed for prolactin and progesterone. Prolactin concentrations in serum were determined by a homologous double-antibody RIA according to the method of Bevers et al. (1978), after some adaptations. Rabbit antiserum 7703-L diluted 1:4000 in normal rabbit serum was used instead of antiserum 7703$\mathrm{K}$ diluted 1:2500. For the standard curve, a porcine prolactin preparation from Tucker Endocrine Research Institute, LLC (Tucker, GA) was used. The assay sensitivity was $0.2 \mathrm{ng} \mathrm{mL} \mathrm{m}^{-1}$, the intraassay $\mathrm{CV}$ was $2.9 \%$ and the interassay $\mathrm{CV}$ was $8.9 \%$. Progesterone concentrations in plasma were measured within a single assay, with an RIA using a commercial kit (ref. IM1188, Beckman Coulter, Roissy CDG, France). The intraassay $\mathrm{CV}$ was $5.8 \%$ and the assay sensitivity was $0.1 \mathrm{ng} \mathrm{mL}^{-1}$. Colostrum samples were analysed for lactose, $\mathrm{Na}$, and $\mathrm{K}$ contents. Lactose is known to be related to milk yield, due to its osmotic component, and the $\mathrm{Na} \mathrm{K}^{-1}$ ratio in milk is indicative of the quality of the mammary tight junctions. Lactose was assayed using an enzymatic method (ref. 01766303, Lactose/D-galactose test combination, R-Biopharm, Darmstad, Germany) and the $\mathrm{Na}$ and $\mathrm{K}$ contents were determined with a Konelab 20i multichannel analyzer with ion selective electrodes after a dilution with a solution for urine (Ref 980303, Thermo Electron Corporation, Cergy Pontoise, France).

All data were analysed by ANOVA using the MIXED procedure of the SAS Institute, Inc. (2002). The sows or the litter represented the experimental unit in the model, which included feeding regime, parity (1-5), and their interaction as fixed effects and batch (1-4) as random effect. Time-related variations in concentrations of hormones were analysed using the procedure for repeated measurements. Correlations between hormone concentrations in sows on the three sampling days and piglet growth rate in the first $24 \mathrm{~h}$ postpartum or from days 1 to 5 postpartum were calculated for all animals with the CORR procedure. Since there were no significant effects of the feeding regime or its interaction on any of the variables measured, only parity effects and correlations are mentioned in the results.

At $108 \mathrm{~d}$ of gestation, mean sow body weight and backfat thickness averaged $252.8 \pm 3.8 \mathrm{~kg}$ and $17.2 \pm 0.3$ $\mathrm{mm}$, respectively, over all sows. Farrowing duration averaged $255 \pm 15 \mathrm{~min}$. Litter characteristics and piglet growth rates for all animals are shown in Table 1 . The mean percentage of stillborn piglets was $9.5 \pm 1.4 \%$. Progesterone concentrations sharply decreased $(P<$ $0.001)$ between day -1 and day $1(10.46 \pm 0.49,6.67 \pm$ 0.35 , and $1.41 \pm 0.12 \mathrm{ng} \mathrm{mL}^{-1}$ on day -1 , day 0 and day 1 , respectively) and were not affected by parity $(P>$ $0.10)$. Prolactin concentrations were influenced by parity $(P<0.001)$ and day of sampling $(P<0.001)$ but the parity $\times$ day interaction was not significant $(P>0.10)$. 


\begin{tabular}{lcc}
\hline \multicolumn{3}{l}{ Table 1. Litter characteristics for the $\mathbf{5 0}$ sows used in the trial } \\
\hline Item & $\mathrm{SE}^{\mathbf{z}}$ \\
\hline $\begin{array}{l}\text { Litter size } \\
\text { Total born }\end{array}$ & 14.4 & 0.4 \\
Born alive & 12.9 & 0.3 \\
Stillborn & 1.5 & 0.2 \\
Litters & & \\
$\mathrm{BW}^{\mathbf{y}}$ at birth, $\mathrm{kg}$ & 19.0 & 0.4 \\
$\mathrm{BW}$ gain for $24 \mathrm{~h}^{\mathbf{x}}(\mathrm{kg})$ & 1.12 & 0.08 \\
$\mathrm{BW}$ gain from day $1^{\mathbf{w}}$ to day $5(\mathrm{~kg})$ & 8.17 & 0.23 \\
\hline
\end{tabular}

${ }^{\mathrm{z}} \mathrm{SE}$, standard error.

${ }^{\mathbf{y}} \mathrm{BW}$, body weight.

${ }^{\mathrm{x}} \mathrm{BW}$ gain for $24 \mathrm{~h}$, starting at the end of farrowing.

"After cross-fostering.

Prolactin concentrations increased between day -1 and day 0 to then decrease between day 0 and day 1 , while remaining greater than before farrowing (Fig. 1). Prolactin concentrations were lower $(P<0.05)$ in sows from parity 1 than in sows from all other parities, they were intermediate in parities 2, 3 and 4 , and were greater $(P>0.05)$ in parity 5 sows, but this value did not differ from that of parity 4 sows $(P>0.10$; Fig. 1$)$. There was no parity effect $(P>0.10)$ but there was a day effect $(P<0.001)$ on the prolactin to progesterone ratio. This ratio was $6.4 \pm 1.3,14.5 \pm 1.5$ and $61.9 \pm 7.6$ on day -1 , day 0 and day 1 , respectively. The ratio was greater $(P<0.05)$ on day 1 than on day -1 and day 0 . Lactose and the $\mathrm{Na} \mathrm{K}^{-1}$ ratio in colostrum were not affected by parity $(P>0.10)$. Mean lactose concentration in colostrum was $2.48 \pm 0.05 \mathrm{~g}$ per $100 \mathrm{~g}$ of fresh

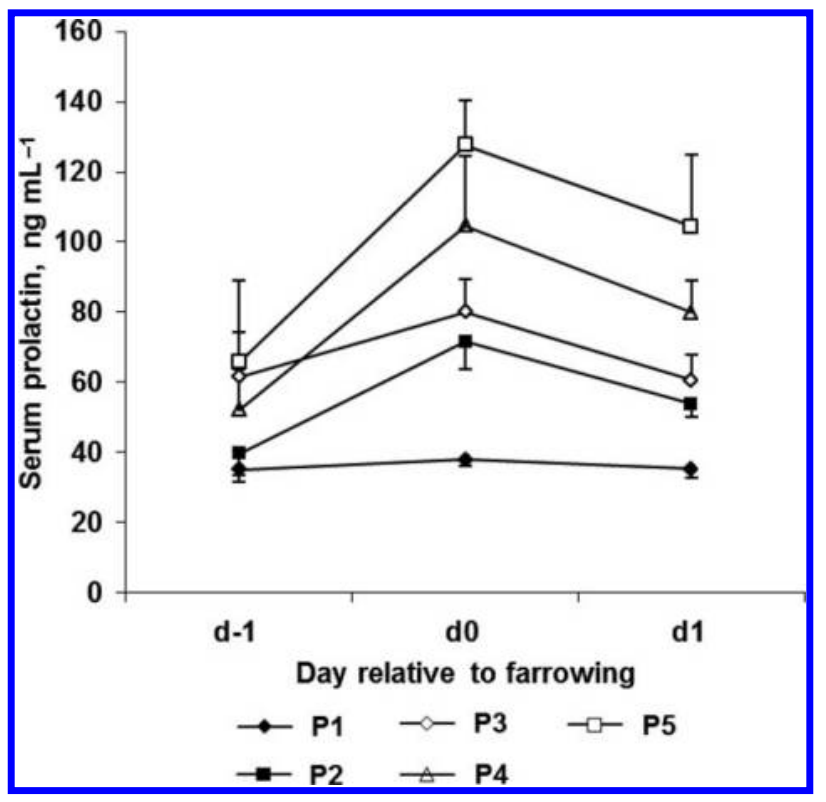

Fig. 1. Serum concentrations of prolactin on the day before (day -1 ), of (day 0) and after (day 1) farrowing according to sow parity (from 1 to 5 ). Day effect, $P<0.001$; parity effect, $P<0.001$; day $\times$ parity interaction, $P>0.10$. colostrum and the $\mathrm{Na} \mathrm{K}^{-1}$ ratio in colostrum averaged $0.99 \pm 0.07$. Lactose concentrations were positively correlated with prolactin concentrations in sows on day 0 $(r=0.33, P=0.02)$ and day $1(r=0.37, P=0.008)$. Litter weight gain during the first day post-partum was not significantly correlated with any measured variables, but litter weight gain between day 1 and day 5 was negatively correlated with progesterone concentrations in sows on day $1(r=-0.34, P=0.01)$.

It is known that piglet growth rate during the first day after birth is strongly correlated to colostrum intake (Devillers et al. 2004a) and although colostrum yield was not estimated in the present study, litter growth over the first $24 \mathrm{~h}$ post-partum provides a good estimate of colostrum yield. Lactose is the principal osmotic component in the mammary secretions which favours water transfer into the lumen of the alveoli (Leong et al. 1990), and thereby increases colostrum and milk yield. The $\mathrm{Na} \mathrm{K}^{-1}$ ratio in colostrum is inversely related with mammary epithelium integrity during lactation (Sørensen et al. 2001), and therefore was used as an indicator of mammary epithelium integrity in the current trial. Both reduced concentrations of lactose and greater $\mathrm{Na} \mathrm{K}^{-1}$ ratio in colostrum have been associated with early hypogalactia in sows (Foisnet et al. 2010). In many species, there is evidence that lactose synthesis by mammary epithelial cells is stimulated by prolactin and inhibited by progesterone. Indeed, the expression of $\alpha$-lactalbumin is up-regulated by prolactin (Tucker 2000), whereas progesterone down-regulates lactose synthase activity (Kuhn 1969). Consistently, lactose concentrations in colostrum were positively correlated with circulating prolactin concentrations in sows in the present study. However, no negative correlation was found between colostral lactose and circulating progesterone, which contrasts with previous findings (Holmes and Hartmann 1993; Devillers et al. 2004b).

Progesterone and prolactin are the major hormones involved in the initiation of milk production. A negative correlation between progesterone concentrations after farrowing and litter growth in early lactation was previously reported (de Passillé et al. 1993) and current results corroborate that finding. Variation in plasma progesterone concentrations around farrowing may have various origins. In the pig, the placental contribution to maternal progesterone is low and pregnancy is maintained by luteal progesterone secretion (Craig 1982). An incomplete or slow process of luteolysis could affect the drop in progesterone around farrowing. Given that progesterone is lipophilic, adipose tissue also could constitute a source of progesterone. Large body fat reserves or adipose tissue catabolism in late pregnancy could release progesterone into blood, and thereby attenuate the drop of circulating progesterone concentrations around farrowing. However, this has not been demonstrated yet. 
The present study shows an effect of sow parity on prolactin concentrations in the peripartum period, with prolactin being lesser in younger sows (1st versus $2 \mathrm{nd}$, $3 \mathrm{rd}$, 4th and 5th parities). This is in agreement with earlier findings, whereby prolactin concentrations were lower in first- than second-parity sows at $24 \mathrm{~h}$ postpartum (Farmer et al. 1995) or in the $10 \mathrm{~d}$ surrounding parturition (Kopinski et al. 2007). It also provides further information in establishing that this effect is due to differences between primiparous and multiparous sows. Furthermore, it demonstrates that older sows have greater concentrations of prolactin in the peripartal period than younger sows.

The authors gratefully acknowledge the staff in Nutreco, J. Lamers, J. Weerts, J. van Wely, and I. Huerta, for the work in the farm and non-surgical catheterisation, and C. David (INRA Saint-Gilles) for progesterone, lactose, $\mathrm{Na}$, and $\mathrm{K}$ assays.

Bevers, M. M., Willemse, A. H. and Kruip, Th. A. M. 1978. Plasma prolactin levels in the sow during lactation and the postweaning period as measured by radioimmunoassay, Biol. Reprod. 19: 628-634.

Craig, V. A. 1982. Placental steroid metabolism in late pregnancy. Pages 405-418 in D. J. A. Cole and G. R. Foxcroft, eds. Control of pig reproduction. Butterworths, London, UK. de Passillé, A. M. B., Rushen, J., Foxcroft, G. R., Aherne, F. and Schaefer, A. 1993. Performance of young pigs: relationship with periparturient progesterone, prolactin and insulin of sows. J. Anim. Sci. 71: 179-184.

Devillers, N., van Milgen, J., Prunier, A. and Le Dividich, J. 2004a. Estimation of colostrum intake in the neonatal pig. Anim. Sci. 78: 305-313.

Devillers, N., Farmer, C., Mounier, A. M., Le Dividich, J. and Prunier, A. 2004b. Hormones, IgG and lactose changes around parturition in plasma, and colostrum or saliva of multiparous sows. Reprod. Nutr. Dev. 44: 381-396.

Devillers, N., Le Dividich, J. and Prunier, A. 2011. Influence of colostrum intake on piglet survival and immunity. Animal 5: $1605-1612$.
Farmer, C., Robert, S., Matte, J. J., Girard, C. L. and Martineau, G. P. 1995. Endocrine and peripartum behavioral responses of sows fed high-fiber diets during gestation. Can. J. Anim. Sci. 75: 531-536.

Farmer, C., Robert, S. and Rushen, J. 1998. Bromocriptine given orally to periparturient or lactating sows inhibits milk production. J. Anim. Sci. 76: 750-757.

Foisnet, A., Farmer, C., David, C. and Quesnel, H. 2010. Relationship between colostrum production by primiparous sows and sow physiology around parturition. J. Anim. Sci. 88: $1672-1683$.

Holmes, M. A. and Hartmann, P. E. 1993. Concentration of citrate in the mammary secretion of sows during lactogenesis II and established lactation. J. Dairy Res. 60: 319-326.

Kopinski, J. S., Blaney, B. J., Downing, J. A., McVeigh, J. F. and Murray, S-A. 2007. Feeding sorghum ergot (Claviceps africana) to sows before farrowing inhibits milk production. Aust. Vet. J. 85: 169-176.

Kuhn, N. J. 1969. Progesterone withdrawal as the lactogenic trigger in the rat. J. Endocrinol. 44: 39-54.

Le Dividich, J., Rooke, J. A. and Herpin, P. 2005. Review: Nutritional and immunological importance of colostrum for the newborn pig. J. Agric. Sci. 143: 469-485.

Leong, W. S., Navaratnam, N., Stankiewicz, M. J., Wallace, A. V., Ward, S. and Kuhn, N. J. 1990. Subcellular compartmentation in the synthesis of the milk sugars lactose and $\alpha$-2,3-sialyllactose. Protoplasma 159: 144-159.

Matte, J. J. 1999. A rapid and non-surgical procedure for jugular catheterization of pigs. Lab. Anim. 3: 258-264.

SAS Institute, Inc. 2002. SAS statistical analysis system, Release 9.2, SAS Institute, Inc., Cary, NC.

Sørensen, A., Muir, D. D. and Knight, C. H. 2001. Thrice-daily milking throughout lactation maintains epithelial integrity and thereby improves milk protein quality. J. Dairy Res. 68: 15-25. Taverne, M., Bevers, M., Bradshaw, J. M. C., Dieleman, S. J., Willemse, A. H. and Porter, D. G. 1982. Plasma concentrations of prolactin, progesterone, relaxin, and oestradiol-17 $\beta$ in sows with progesterone, bromocriptine or indomethacin during late pregnancy. J. Reprod. Fert. 65: 85-96.

Tucker, H. A. 2000. Hormones, mammary growth, and lactation: A 41-year perspective. J. Dairy Sci. 83: 874-884. 